\title{
Intelligence neurocircuitry: cortical and subcortical structures
}

\author{
DAMIANI, D. ${ }^{1}$, PEREIRA, L. K. ${ }^{1}$, DAMIANI, D. ${ }^{2}$ and NASCIMENTO, A. M. ${ }^{1}$ \\ ${ }^{1}$ Departamento de Pós-Graduação em Neurociências, Universidade Anhembi Morumbi, Rua Casa do Ator 275, \\ Vila Olímpia, CEP 04546-001, São Paulo, SP, Brasil \\ ${ }^{2}$ Universidade de São Paulo, Av. Dr. Arnaldo 455, Cerqueira Cesar, CEP 01246-903, São Paulo, SP, Brazil \\ ${ }^{*}$ E-mail: dani.neurocirurgia@gmail.com
}

\begin{abstract}
The authors describe the brain regions involved in the process of intelligence using as a basis, the models of the theory of frontoparietal integration ( P-FIT Model). They also correlate the model described with functional areas of Brodmann, integrating them into the tertiary brain areas and address the subcortical structures involved in cognitive processes, including the memory. The studies performed by functional magnetic resonance, also unmask various regions related with intelligence, neither previously described by Brodmann nor even in conventional models of learning. The anterior insular cortex presents itself as the most recent tertiary area to be considered. Subcortical structures, when injured, mimick injuries to the cerebral cortex, demonstrating their great participation in cognition. The topographies of aphasia and the functioning mechanisms of the bearers of learning disorders, including dyslexic, dysgraphia and dyscalculic should be reconsidered. A better understanding of this topographic anatomy may clarify the mechanisms used in those individuals with cerebral lesions.
\end{abstract}

Keywords: intelligence, neuroanatomy of cognition, neurocircuitry of intelligence, cognitive mind, neurocognitive science.

\section{Introduction}

The intelligence can be defined as the mental skill for the thought, logic and abstract thinking as well as for the learning. Due to its wide spectrum, the intelligence integrates the cognitive functions or high cortical skills, including perception, attention, memory, language, and planning. According to the definition, the intelligence can be assessed and measured through diverse clinical tests that explore the multiple areas of cognition. The studies of functional neuroimaging bring to the neurosciences a better comprehension of the anatomy of intelligence, using the brain mechanisms of learning put by the recent theory of frontoparietal integration ( $P$-FIT model), as the basic structural principle. A wider definition of intelligence, described by 52 researchers in cognitive neurosciences, considers that the intelligence is a general capacity that encompasses the skill to think, plan, solve problems, think abstractly and, understand complexes ideas, to have a quick learning and to learn with experience. The modern neuroscience defines "global intelligence (g)" as the capacity of integrate and articulate the following modalities of thinking: speed in the information processing, cognitive speed, skill of remembering, auditive and visual perception, memory and learning capacity, fluid and crystalized intelligence. The crystalized intelligence is one that improves as time goes by and it is natural that the vocabulary increases with age. The fluid intelligence diminishes as time goes by since it measures the speed to access information, abstraction capacity and the ability to store new information. In the above the level brains, as well as in the super gifted, Haier et al emphasize that the thickness of cortex can, at least in part, explain a greater efficiency in the information processing. This brain would spend less energy to perform, faster, the same function (JUNG and HAILER, 2007; STERNBERG, 2012).
Some critics of the neurocognitive model of global intelligence consider that, after the publication of Howard Gardner book in 1983 (multiple intelligences), the neuroscientist should start to consider the existence of many "categories" of intelligence, leading an individual to be exceptional in one category and below the mean in others. According to Gardner there are nine categories of intelligence, each one working on an independent way in the human brain: linguistic, corporeal-kinesthetic, musical, existential, spatial, interpersonal, intrapersonal, naturalistic, and spiritual. According to Gardner, these categories are based only on empirical conclusions, without any scientific support. To Gardner a super gifted would be an individual with exceptionality in one of the categories described. The current scientific evidences point out that the neurocircuitry of intelligence and learning do not favor the Howard Gardner's empiric theory and the super gifted are individuals that possess different phases of development and cortical maturation, compared to the general population and, besides, they possess a greater cerebral efficiency associated with a thicker cortex (JUNG and HAILER, 2007; STERNBERG, 2012; LUDERS, NARR, THONPSOM, 2009).

The authors performed a bibliographic review describing the knowledge on the brain mechanisms of intelligence, using these databases: MedLine, PubMed, SciELO, and Cochrane.

\section{Development}

\subsection{Intelligence neuronal circuitry (Fronto- Parietal Integration - P-FIT Model)}

Where is the intelligence in the human brain? For centuries, this question seeks an answer, since the phrenology with Gall in 1825 , Broca in 1861, Wernicke in 1874, the famous case of 
Phineas Gage, reported by Harlow in 1848 and Brodmann in 1909 , the scientists try to functionally map the human brain.

After the publication of the fronto-parietal integration model, describing the regions related to the learning process, many areas associated to the process of acquisition of information and primary cortical responsible for the first processing of the information have been highlighted. The temporal and occipital regions are considered the primary sensory receptor areas of information, being the occipital lobe responsible for the reception and reconstruction of the visual information (Brodmann areas 17, 18, and 19). The temporal lobe is responsible for the auditive information (Brodmann areas 41, $42,22 \mathrm{~A}$, and $22 \mathrm{~B}$; the last one, considered part of associative area integrate the parieto-occipitotemporal lobes, correspond to Wernicke areas).

The Brodmann area 37, located in the occipito-temporal transition, is responsible for the integration and recognition of the images received by the areas 17, 18, and 19. Lesions in this area 37 go with anosmia and prosopagnosia (inability to recognize faces).

The integration and interpretation of the primary sensory information (Brodmann areas 3a, 3b, 1, and 2, located at post-central gyrus) is done in the supramarginal and angular gyrus, as well as in the parietal superior lobule (Brodmann area 7). Parietal areas interact with frontal areas of the frontal lobe for a tertiary processing of the information, evaluating the problem, testing hypotheses and giving resolution (Brodmann areas $6,9,10,45,46$, and 47$)$. In the end, the anterior cingulate gyrus (Brodmann area 32 ) chooses the best option of response, inhibiting and getting rid of the alternative possibilities.

The white matter, specially the arcuate fasciculus, is organized in the form of fibers that intercommunicate the language centers, correlating the areas of Wernicke and Broca, being known as the Geschwind area, that intercommunicate the frontal to the parietal, temporal, and occipital lobes.

On the other side, however, Jung and Haier suggest that not only the Broca and Wernicke areas are necessary to the intelligence but also other areas such as the pre-frontal dorsolateral cortex (Brodmann areas 9, 45, 46, and 47) and parietal cortex (Brodmann areas 7 and 40) essential to the process of global intelligence (g) (Figure 1).

The frontoparietal circuits are relevant to the work memory, as demonstrated by studies of functional magnetic resonance (fMRI). Rex and Jung uses structural neuroimaging studies including tractography (DTI), voxel based morphometry (VBM) and resonance with spectrometry (MRS) to compare the size of brain areas related to intelligence and performance in the Wechsler scale for adults (WAIS) and children (WISC) (JUNG and HAILER, 2007; BARBEY, COLOM, SOLOMON et al, 2012). The global intelligence correlates with work memory and maybe both share the same neuronal tracts. The left prefrontal area (Brodmann Area 10) correlates specially with global intelligence (g) having the necessary means to allow success in cognitive performances. Although it seems important for the composition of $\mathrm{g}$, in the cases of prefrontal lobotomies, we do not see problems with the global intelligence. There has been found strong association of the thickness of the cortex in certain regions and the global intelligence, specially in the lateral prefrontal striated, occipital, and parahippocampal (JUNG and HAILER, 2007; COLOM, KARAMA, JUNG et al., 2010; CATANI, JONES and FFYTCHE, 2005; FISCHER, WOLF, SCHEURICH et al., 2014; DUNCAN, 2013).

The process of acquisition of knowledge and the formation of global intelligence is dynamic and, according to the age, correlates to a determined brain region with variable intensity: while children have more activity related to the anterior cingulate

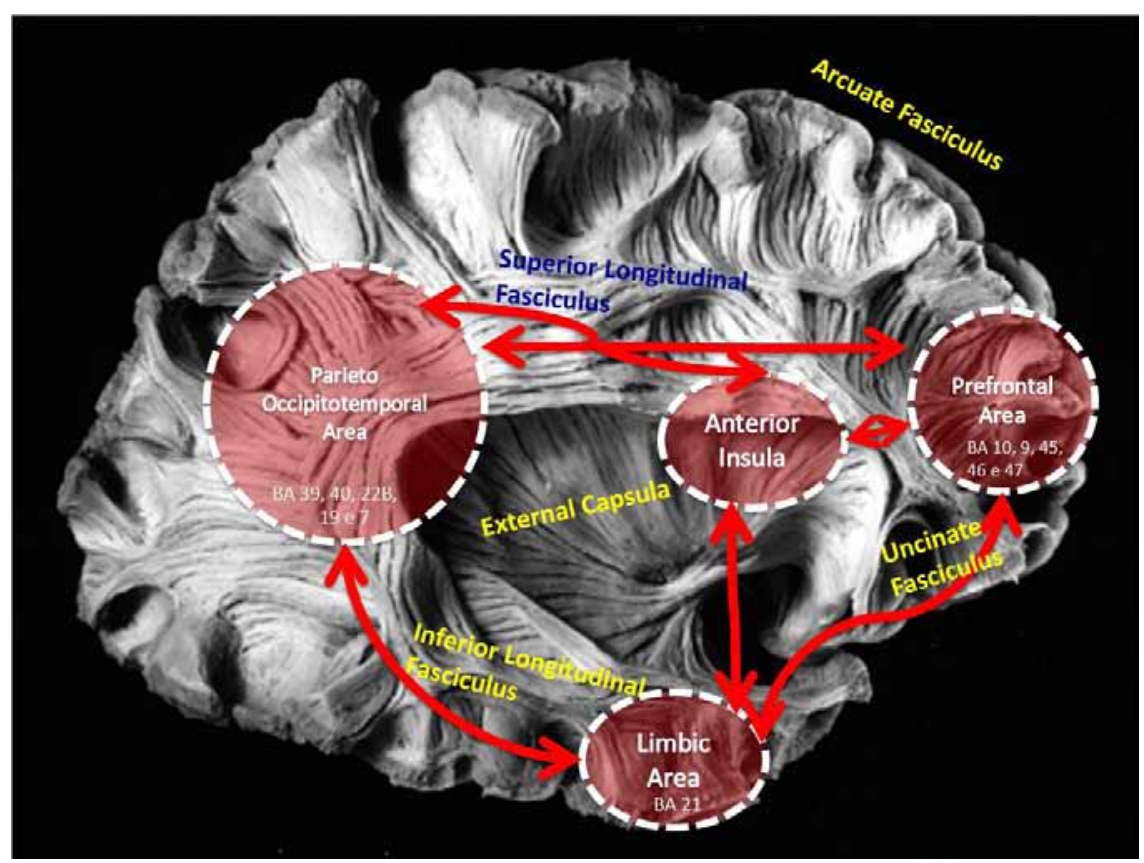

Figure 1. Intelligence brain circuits. The figure is based on cerebral models of learning (P-FIT Model) described by Jung RE et al in 2007, including the related Brodmann areas as well as the fascicules that communicate various tertiary centers of information, highlighting the areas of association: parieto-occipitotemporal (traditional Wernicke's area); limbic association area; prefrontal association area and anterior insular cortex area. 
gyrus, in adolescents, the orbitofrontal and medial prefrontal cortex are involved. In adults, the most intense activity in the lateral prefrontal cortices (BA 9, 10, 11). After these new findings, more research in the topography of the aphasias must be considered.

\subsubsection{Subcortical structures and intelligence}

Using tractography and anatomic studies, many authors observed that lesions in subcortical structures, such as basal nuclei, thalamus, and cerebellum mimetize cortical lesions with some qualitative differences. The pioneers in neurofunctional studies, such as Korbinian Brodmann, Karl Wernicke, and N Geschwind did not consider the white matter or the subcortical structures responsible for the symptoms after brain lesions. Only after the description of subcortical dementia, including the progressive supranuclear palsy, the authors start to consider the subcortical structures as responsible for diseases that compromise cognition.

\subsubsection{Basal nuclei}

The first correlations between the basal nuclei and cognitive function were made in cases of Huntington chorea and in the progressive supranuclear palsy. Since then, the subcortical dementia has been associated to lesions of these nuclei, which causes slowing of thinking, apathy, forgetfulness, and depression. Later, correlation between subcortical dementia and mood, excitation, attention, motivation, language, memory, abstraction and visuospatial functions were described. Patients with Parkinson's disease also show alterations of behavior, including dementia associated to motor disturbances. Lesions involving the caudate nucleus lead to compromised work memory, aphasia, cognitive and strategic flexibility. In the non-dominant hemisphere, the lesion of caudate nucleus can lead to heminegligency and visuospatial disorientation. Lesions of the ventral striatum nucleus lead to disinhibiting of behavior, irritation, addiction (reward circuit) and obsessive-compulsive disorder. Lesions in the putamen can lead to extrapyramidal syndrome symptoms, including akinesia and apathia (SCHMAHMANN and PANDYA, 2008).

\subsubsection{Thalamus}

The first to describe cognitive symptoms associated to thalamus hemorrhage was Fisher in 1959. He described symptoms of negligence, anosognosia and hemiassomatognosia with visual hallucinations and mental confusion, but the lesions were seldom related to the thalamus itself. There are four big vascular syndromes related to thalamus lesions:

A) Infarction of the tuberothalamic artery: the patients present fluctuations on the level of conscience, time and space disorientation, personality disturbance (euphoria, apathy, loss of spontaneity, lack of insight). Also compromised are new learning, verbal and visual memories. Lesions of the left tuberothalamic artery are associated with amnesia with anosmia, aphasia, perseveration, semantic and phonemic mistakes. Acalculia and bucofacial apraxia can also occur. Lesions on the right side are associated with hemispatial negligence and loss of visuospatial memory. Bilateral lesions can cause central facial paralysis to the involuntary movement (maintaining the voluntary movement) and constructive apraxia;
B) Infarction of paramedian artery: can cause agitation, dysfunction of memory and excitation, aggressively, apathy and perseveration. Left side lesions can lead to aphasia and loss of verbal fluency, occasional paraphasias, maintaining the syntaxes and repetition. Right-sided lesions compromise visuospatial functions. In bilateral lesions, there are alterations of level of conscience, disorientation, confusion, akinetic mutism, anterograde and retrograde amnesia, emotional lability, apathy and apraxia with dysgraphia;

C) Infarction of the inferolateral artery: usually associated to Dejerine Roussy syndrome, with sensorial loss, hemiparesis and intense post-lesional pain. There has not been description of cognitive and affective disturbances in this kind of lesion;

D) Infarction of posterior choroidal artery: vascular accidents in this artery go with complex visual alterations, reflecting the involvement of lateral geniculate body, transcortical aphasia, memory deficit and sensorial loss. Spatial negligence can be found, as well as late motor alterations such as ataxias, dystonia, rubral tremor, myoclonus and chorea.

Some syndromes can be better understood if we consider the thalamus division by nuclei:

a) Reticular thalamic nucleus: it is a GABAergic nucleus that regulate the rhythmicity of other thalamic nuclei, inducing sleep, for instance. They are important to the learning process, inducing focus and attention in the correct moment to allow learning;

b)Thalamic intralaminar nucleus: responsible for the brainstem afferent specially for the nociception tracts and the ascending activator reticular system;

c) Limbic nuclei: they are composed of ventral dorsal and medial nuclei, they participate in learning and memory, as well as motivation and personal experience;

d)Thalamic specific nuclei: lateral and medial geniculate body, responsible, respectively for vision and hearing;

e) Effector thalamic nuclei: receive afferent from pallidum and communicate with premotor areas, supplemental motor areas and posterior parietal lobe. They are related to motor functions and verbal fluency;

f) Thalamic association nuclei: they connect with cortical areas of association, and they are related to complex cognitive functions (Figulre 2) (DUNCAN, 2013; PINAULT, 2004; HALASSA, CHEN, WIMMER et al., 2014).

\subsubsection{Cerebellum}

The dogmatic concept on the exclusively motor functions for the cerebellum has been destroyed. Besides the motor functions, cerebellar lesions can cause cognitive and affective problems. The anterior lobe is related to motor activity. Lesions in this region lead to ataxia, dysmetry, incoordination, dysarthria and visuomotor alterations. In lesions involving the cerebellar hemispheres as well as the lesions in the posterior lobe, symptoms include cerebellar cognitive-affective syndromes, 


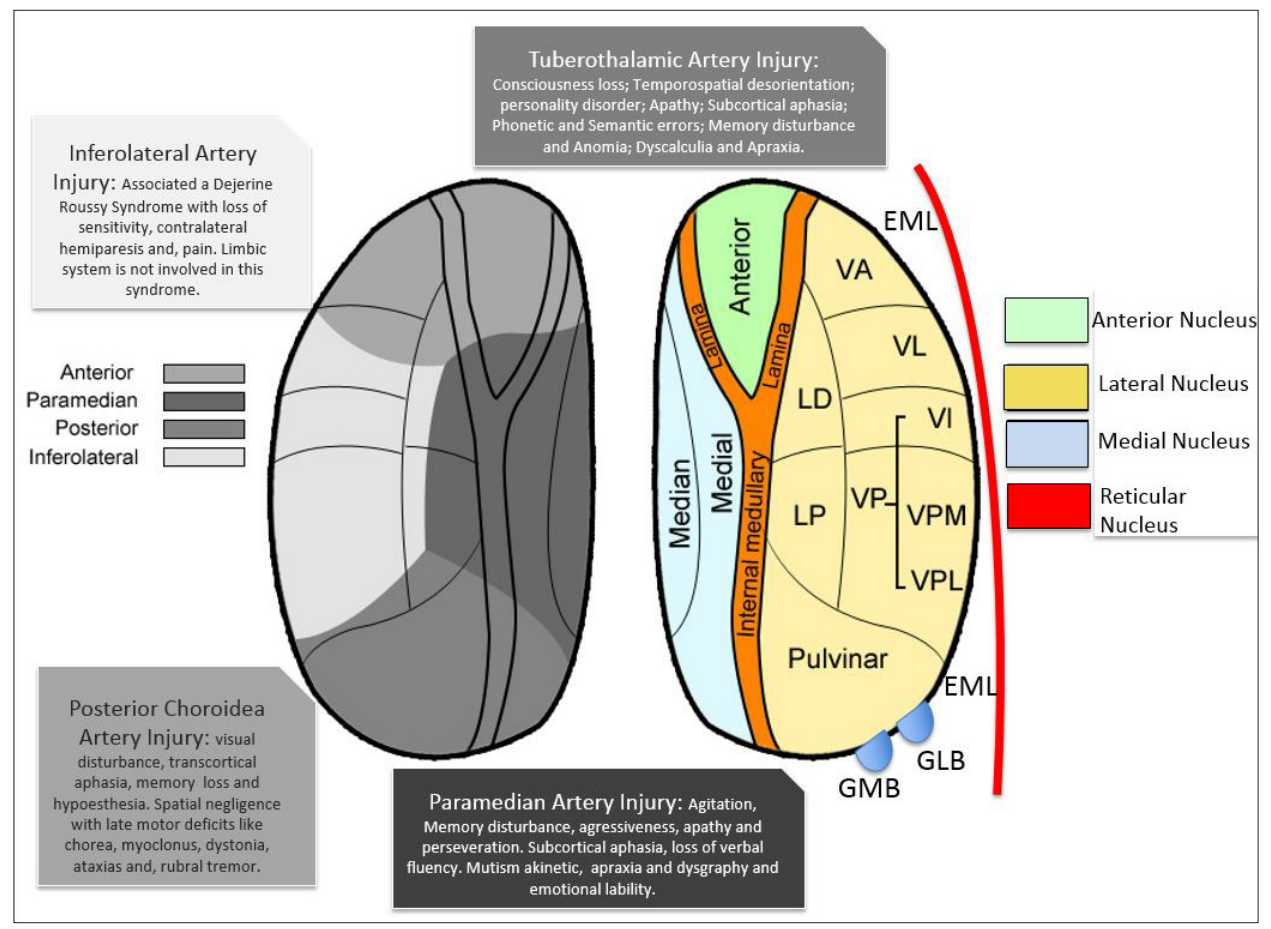

Figure 2. Thalamic nuclei with their nutritional arteries and, majors clinical lesion manifestation. On the left-hand side, we highlight the cognitive symptoms related to isolated lesions of these areas. On the right-hand side, we depict the main thalamic nuclei and their functional divisions. VA - ventral anterior; VL - ventral lateral; VP - ventral posterior: subdivided in VI - ventral intermedial; VPM - ventral posteromedial; VPL - ventral posterolateral; LP - lateral posterior; LD - dorsal-lateral; GLB - geniculate lateral body; GMB - geniculate medial body; EML - external medullar lamina.

such as deficit in execution functions, visuospatial alterations, language problems and affective disorders. In the posterior fossa syndrome (one type of cerebellar cognitive-affective syndrome) that occurs 48 hours after the excision of a cerebellar tumor, children show mutism, buccolingual apraxia, apathy and poor spontaneous movements. Emotional lability is evident with distraction, irritability and agitation (Figure 3) (SCHMAHMANN and PANDYA, 2008; PINAULT, 2004; HALASSA, CHEN, WIMMER et al., 2014; STOODLEY and SCHMAHMANN, 2010; VOOGD, 2003; CAHANA-AMITAY and ALBERT, 2014).

\subsubsection{Neurotransmitters and functional areas}

Through studies with fMRI (functional magnetic resonance imaging) it has been suggested that the polymorphism of genes controlling the catechol-o-methyl-transpherase enzyme (COMT) in the prefrontal region is associated to blood hypoperfusion in this region. The mutation Vall58Met gene correlates with higher activity of COMT and global reduction of dopamine in the prefrontal circuits of learning. The deficit in the fluid intelligence, activity of dorsolateral prefrontal cortex, premotor area, supplemental motor area, anterior cingulate gyrus, and intraparietal sulcus is related to less dopamine in these areas (BISHOP, FOSSELLA, CROUCHER et al., 2008).

\subsubsection{Brain white matter}

Through studies of tractography - diffusion tensor imaging (DTI), emphasis has been put to the white matter concerning the learning circuits and global intelligence. With DTI we get information on the size, orientation, geometry and axonal myelination. The indices of fractioned anisotropy in the frontoparieto-occipital regions correlate directly with global intelligence scores, evaluated through Wechsler scale. These parameters obtained by DTI reflect the organization of the white fibers, as well as their densities in the areas related to intelligence. Those who show higher Wechsler scores exhibit more integrity of the uncinate fasciculus white matter in the right hemisphere. Those with mental retardation show DTI with fractioned anisotropy, big lesions with loss of integrity of the fibers that compose the corpus callosum, uncinate fasciculus, optic radiation and corticospinal tract (YU, LI, LIU et al., 2008). Chian et al showed that the integrity of white fibers is genetically determined (COLOM, KARAMA, JUNG et al., 2010).

\subsubsection{Neuronal information network related to intelligence}

Individuals with high level intelligence have more efficiency in the transfer of brain information, including a interhemispheric and intrahemispheric network of information. They have more capacity to interlink the frontal regions with the parietal, temporal, occipital and limbic lobes. Recent work using the connectome project has shown the multiple circuits involved in the global intelligence, concluding that there is an intelligence circuit with uniform cytoarchitecture among the human brains and quite different when comparing men and women (Figure 1) (OHTANI, NESTOR, BOUIX et al., 2014; BISWAL, MENNES, ZUO et al., 2010).

\subsubsection{Thickness of cerebral cortex and its correlation with global intelligence}

The process of intelligence acquisition is dynamic and, at all times, the cortical plasticity looks for a better adaptation of the individual to life situations. Shaw $\mathrm{P}$ et al observed that the 


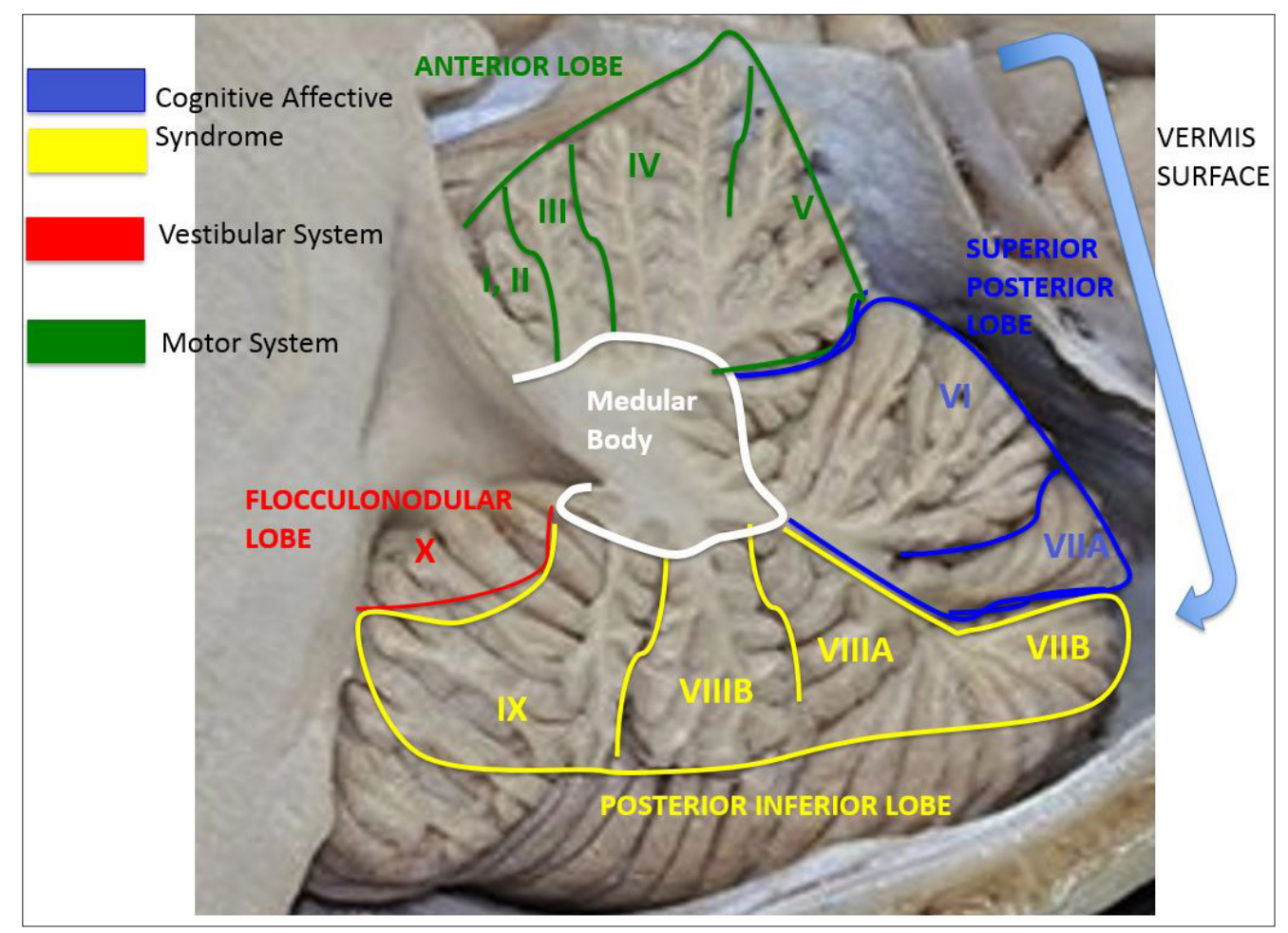

Figure 3. Cerebellum functional topography. Functional Larsell areas are represent in roman numbers (I-X) and functional subdivision is seem by vermis surface: Green - motor system located in anterior cerebellar lobe; Blue / Yellow - represent cognitive and affective functions; Red - correspond a vestibular area.

development of the brain cortex, specially for the prefrontal cortex, is related to the global intelligence. Studies with intelligence above the mean and the super gifted, evaluated by Wechsler score, show that these kids have a more accelerated phase of cortex maturation and development as well as a more accelerated pruning in the initial phases of adolescence. Another factor responsible for modulating the intelligence neurocircuitry is related to the phenomenon of use-dependent synaptic formation and, on the opposite end, the lack of use abolishing the circuit. The prefrontal cortex shows a later structural and metabolic maturation compared with other areas of intelligence, having a critical window of development (SHAW, GREENSTEIN, LERCH et al., 2006).

\subsubsection{Genetic influence in the global intelligence}

The original idea that intelligence has a genetic origin and would be transmitted through generations was first described by Francis Galton, in two papers published in the XIX century. After a lot of criticism, many studies were planned with the aim of contradicting Galton's theory, but they failed. Genetic influence on intelligence is responsible for $30-80 \%$ of variation according to the component of intelligence studied. Genetic has major influence on the verbal and perceptual components, and on organizational skills. It has less influence on memory capacity. When we analyze the density and the volume of white and gray matter in the corpus callosum, upper frontal lobe, temporal cortex, amygdaloid complex, hippocampus, medial frontal cortex, anterior cingulate area, postcentral gyrus, Heschl transverse gyrus and Broca area, the genetic influence is directly implicated in the brain mechanisms of intelligence.
The cortical thickness, for instance, is determined by genetic components with a strong influence that varies between 77 and $88 \%$. Since it is a dynamic process, the various brain areas related to intelligence have different genetic interferences according to the age. Somatosensory primary areas, for instance, are under the influence of genetics, since its development occurs in the first weeks of the intrauterine life. On the other hand, temporal lobes and the dorsal prefrontal cortex receive stronger genetic influence in adolescence, a critical time of development. Being a dynamic and complex mechanism of interference, it is difficult to establish a single gene responsible for the whole process. In cases of mental retardation, more than 300 genes are candidates, most of them related to neurotransmitters and with brain metabolism. In the elderly, it seems that the polymorphism APOE is related with cognitive skills, episodic memory, speed or processing and executive function. The COMT (catechol-o-methyl transferase) polymorphisms relate directly and strongly with IQ scores. The polymorphic gene that leads to a Vall66Met mutation in the protein alters the activity of brain-derived neurotrophic factor (BDNF), interfering with cognitive functions (DUNCAN, 2013; OHTANI, NESTOR, BOUIX et al., 2014; PAMPLONA, SANTOS NETO, ROSSET et al., 2015; KOTEN JUNIOR, WOOD, HAGOORT et al., 2009; DEARY, PENKE and JOHNSON, 2010).

\subsubsection{Brain size and human intelligence}

Recent studies have demonstrated a positive correlation between the brain size and global intelligence. More gray matter reflects more neuronal cells density (measured by spectroscopic $\mathrm{N}$-acetylaspartate) bigger synaptic interconnection network and more dendritic arborization. We can consider that a bigger 
brain reflects thicker axons that go through the white matter as well as a major degree of myelination. Gray matter reflects the capacity of information processing, while the white matter is responsible for the transmission of information inside de central nervous system. Tractography to evaluate the white matter confirms the hypothesis that more axonic density is correlated with better global intelligence (DEARY, PENKE and JOHNSON, 2010). Once agreed that "bigger brain means intelligence", which is observed in the species evolution (SCHMITHORST, WILKE, DARDZINSKI et al., 2005), two genes were identified as regulate of brain size: microcephalin $(\mathrm{MCPH})$ and abnormal spindle-like microcephaly-associated protein (ASPM). Microcephalin mutations (including G37995C) found in the germinative matrix lead to mental retardation associated to the maintenance of global brain architecture. Homozygous mutations in the ASPM gene (A44871G and C45126A) is associated with microcephaly leading to anomalous differentiation and proliferation of brainstem cells responsible for the brain growth. ASPM is located on chromosome 1, band q31 (1q31). Defective forms of the ASPM gene are associated with autosomal recessive primary microcephaly, this gene is expressed in the primary sites of prenatal cerebral cortical neurogenesis (YOUSEM, YASSA, CRISTINZIO et al., 2009; CHIANG, BARYSHEVA, MCMAHON et al., 2012). Chiang MC et al found 24 polymorphisms in 6 genes considered responsible for the integrity of the white matter, with direct correlation to the cognitive performance. These genes are related to the maintenance of synaptic integrity of the white matter, activity of neuronal plasmatic membrane and maintenance of sodium channels (CHIANG, BARYSHEVA, MCMAHON et al., 2012).

\subsubsection{Differences between male and female brains}

Male and female brains function differently but they should not be different considering the areas related to the global intelligence. In men, the frontoparietal gray matter is bigger while the Broca area is bigger in women. Women have thicker cortical in frontal regions while in men, the temporo-occipital region cortical is thicker. The integrity of the white matter is more important for women than for men: some studies show that men have a negative correlation between intelligence (evaluated by DTI) and the integrity of frontoparietal fibers after puberty. This fact suggests that the cognitive functions in men are more dependent of less amount of white fibers, but thicker, compared with women. It seems that men have more neuronal efficiency regarding cognitive spatial activities. However, when verbal capacity is evaluated, women are more efficient. Although local specific differences exist regarding global intelligence, male and female brains are quite similar, even considering that the female brain is smaller than the male (DEARY, PENKE and JOHNSON, 2010).

\section{Conclusions}

In a century where the neuroimages clarify many functional aspects of the human brain, the functional areas of Brodmann, described in 1909, keep being the basis of anatomo-functional comprehension. In this context, the authors describe the functional areas of the human intelligence, to a certain point revealed by functional resonance, morphometric studies based in voxel, magnetoencephalograhy, tractography, resonance spectroscopy, positron-emission tomography (PET scan) and single-photon emission tomography (SPECT) which showed direct correlation with tests associated to the intellectual quotient (including Wechsler scale for adults and for children). The subcortical structure, including cerebellum, thalamus and basal nuclei show important correlation with cognitive functions, being able to mimetize cortical lesions when damaged. The model of frontoparietal integration (P-FIT model) match the neuroimaging findings, but many functional studies, according to genre and age, will probably modify the intelligence circuits accepted nowadays. Future pharmacologic interventions will be at hand to stimulate or to inhibit specific neurocircuits involved with cognition, open the way to an effective therapy to learning disturbances and neuropsychiatric diseases (GRAY and THOMPSON, 2004; LUDERS, NARR, THONPSOM, 2009; RHEIN, MÜHLE, RICHTERSCHMIDINGER et al., 2014; PAMPLONA, SANTOS NETO, ROSSET et al., 2015; GLASCHER, TRANEL, PAUL et al., 2009).

\section{References}

BARBEY, AK., COLOM, R., SOLOMON, J., KRUEGER, F., FORBES, C. and GRAFMAN, J. An integrative architecture for general intelligence and executive function revealed by lesion mapping. Brain, 2012, vol. 135, n. 4, p. 1154-1164. PMid:22396393. http:// dx.doi.org/10.1093/brain/aws021.

BISHOP, SJ., FOSSELLA, J., CROUCHER, CJ. and DUNCAN, J. COMT Vall58Met genotype affects recruitment of neural mechanisms supporting fluid intelligence. Cerebral Cortex, 2008, vol. 18, n. 9, p. 2132-2140. PMid:18252743. http://dx.doi.org/10.1093/cercor/ bhm 240 .

BISWAL, BB., MENNES, M., ZUO, XN., GOHEL, S., KELLY, C., SMITH, SM., BECKMANN, CF., ADELSTEIN, JS., BUCKNER, RL., COLCOMBE, S., DOGONOWSKI, AM., ERNST, M., FAIR, D., HAMPSON, M., HOPTMAN, MJ., HYDE, JS., KIVINIEMI, VJ., KÖTTER, R., LI, SJ., LIN, CP., LOWE, MJ., MACKAY, C., MADDEN, DJ., MADSEN, KH., MARGULIES, DS., MAYBERG, HS., MCMAHON, K., MONK, CS., MOSTOFSKY, SH., NAGEL, BJ., PEKAR, JJ., PELTIER, SJ., PETERSEN, SE., RIEDL, V., ROMBOUTS, SA., RYPMA, B., SCHLAGGAR, BL., SCHMIDT, S., SEIDLER, RD., SIEGLE, GJ., SORG, C., TENG, GJ., VEIJOLA, J., VILLRINGER, A., WALTER, M., WANG, L., WENG, XC., WHITFIELD-GABRIELI, S., WILLIAMSON, P., WINDISCHBERGER, C., ZANG, YF., ZHANG, HY., CASTELLANOS, FX. and MILHAM, MP. Toward discovery science of human brain function. Proceedings of the National Academy of Sciences of the United States of America, 2010, vol. 107, n. 10, p. 4734-4739. PMid:20176931. http:// dx.doi.org/10.1073/pnas.0911855107.

CAHANA-AMITAY, D. and ALBERT, ML. Brain and language: evidence for neural multifunctionality. Behavioural Neurology, 2014, vol. 2014, p. 260381. PMid:25009368. http://dx.doi. org/10.1155/2014/260381.

CATANI, M., JONES, DK. and FFYTCHE, DH. Perisylvian language networks of the human brain. Annals of Neurology, 2005, vol. 57, n. 1, p. 8-16. PMid:15597383. http://dx.doi.org/10.1002/ana.20319.

CHIANG, MC., BARYSHEVA, M., MCMAHON, KL., DE ZUBICARAY, GI., JOHNSON, K., MONTGOMERY, GW., MARTIN, NG., TOGA, AW., WRIGHT, MJ., SHAPSHAK, P. and THOMPSON, PM. Gene network effects on brain microstructure and intellectual performance identified in 472 twins. The Journal of Neuroscience, 2012, vol. 32, n. 25, p. 8732-8745. PMid:22723713. http://dx.doi.org/10.1523/JNEUROSCI.5993-11.2012.

COLOM, R., KARAMA, S., JUNG, RE. and HAIER, RJ. Human intelligence and brain networks. Dialogues in Clinical Neuroscience, 2010, vol. 12, n. 4, p. 489-501. PMid:21319494. 
DEARY, IJ., PENKE, L. and JOHNSON, W. The neuroscience of human intelligence differences. Nature Neuroscience, 2010, vol. 11, n. 3, p. 201-211. PMid:20145623.

DUNCAN, J. The structure of cognition: Attentional episodes in mind and brain. Neuron, 2013, vol. 80, n. 1, p. 35-50. PMid:24094101. http://dx.doi.org/10.1016/j.neuron.2013.09.015.

FISCHER, FU., WOLF, D., SCHEURICH, A. and FELLGIEBEL, A. Association of structural global brain network properties with intelligence in normal aging. PLoS One, 2014, vol. 9, n. 1, p. e86258. PMid:24465994. http://dx.doi.org/10.1371/journal.pone.0086258.

GLASCHER, J., TRANEL, D., PAUL, LK., RUDRAUF, D., RORDEN, C., HORNADAY, A., GRABOWSKI, T., DAMASIO, $\mathrm{H}$. and ADOLPHS, R. Lesion mapping of cognitive abilities linked to intelligence. Neuron, 2009, vol. 61, n. 5, p. 681-691. PMid:19285465. http://dx.doi.org/10.1016/j.neuron.2009.01.026.

GRAY, J. and THOMPSON, PM. Neurobiology of intelligence: science and ethics. National Review, 2004, vol. 5, n. 6, p. 471-482. PMid:15152197. http://dx.doi.org/10.1038/nrnl405.

HALASSA, MM., CHEN, Z., WIMMER, RD., BRUNETTI, PM., ZHAO, S., ZIKOPOULOS, B., WANG, F., BROWN, EN. and WILSON, MA. State-Dependent Architecture of Thalamic Reticular Subnetworks. Cell, 2014, vol. 158, n. 4, p. 808-821. PMid:25126786. http://dx.doi.org/10.1016/j.cell.2014.06.025.

JUNG, RE. and HAILER, RJ. The parieto-frontal integration theory (P-FIT) of intelligence: Converging neuroimaging evidence. Behavioral and Brain Sciences, 2007, vol. 30, n. 2, p. 135-187. PMid:17655784. http://dx.doi.org/10.1017/S0140525X07001185.

KOTEN JUNIOR, JW., WOOD, G., HAGOORT, P., GOEBEL, R., PROPPING, P., WILLMES, K. and BOOMSMA, DI. Genetic contribution to variation in cognitive function: an fMRI study in twin. Science, 2009, vol. 323, n. 5922, p. 1737-1740. PMid:19325117. http://dx.doi.org/10.1126/science.1167371.

LUDERS, E., NARR, KL. and THONPSOM, PM. Neuroanatomical Correlates of Intelligence. Intelligence, 2009, vol. 37, n. 2, p. 156-163. PMid:20160919. http://dx.doi.org/10.1016/j.intell.2008.07.002.

OHTANI, T., NESTOR, PG., BOUIX, S., SAITO, Y., HOSOKAWA, T. and KUBICKI, M. Medial frontal white and grey matter contribution to general intelligence. PLoS One, 2014, vol. 9, n. 12, p. el12691. http://dx.doi.org/10.1371/journal.pone.0112691.

PAMPLONA, GS., SANTOS NETO, GS., ROSSET, SRE., ROGERS, BP. and SALMON, SEG. Analyzing the association between functional connectivity of the brain and intellectual performance. Frontiers in Human Neuroscience, 2015, vol. 61, n. 9, p. 1-10. PMid:25713528.

PINAULT, D. The thalamic reticular nucleus: structure, function and concept. Brain Research. Brain Research Reviews, 2004, vol.
46, n. 1, p. 1-31. PMid:15297152. http://dx.doi.org/10.1016/j. brainresrev.2004.04.008.

RHEIN, C., MÜHLE, C., RICHTER-SCHMIDINGER, T., ALEXOPOULOS, P., DOERFLER, A. and KORNHUBER, J. Neuroanatomical correlates of intelligence in healthy young adults: the role of basal ganglia volume. PLoS One, 2014, vol. 9, n. 4, p. e93623. PMid:24699871. http://dx.doi.org/10.1371/journal. pone.0093623.

SCHMAHMANN, J. and PANDYA, DN. Disconnection syndromes of basal ganglia, thalamus, and cerebrocerebellar systems. Cortex, 2008, vol. 44, n. 8, p. 1037-1066. PMid:18614161. http://dx.doi. org/10.1016/j.cortex.2008.04.004.

SCHMITHORST, VJ., WILKE, M., DARDZINSKI, BJ. and HOLLAND, SK. Cognitive functions correlate with white matter architecture in a normal pediatric population: A diffusion tensor MRI study. Human Brain Mapping, 2005, vol. 26, n. 2, p. 139-147. PMid:15858815. http://dx.doi.org/10.1002/hbm.20149.

SHAW, P., GREENSTEIN, D., LERCH, J., CLASEN, L., LENROOT, R., GOGTAY, N., EVANS, A., RAPOPORT, J. and GIEDD, J. Intellectual ability and cortical development in children and adolescents. Nature, 2006, vol. 440, n. 7084, p. 676-679. PMid:16572172. http://dx.doi.org/10.1038/nature04513.

STERNBERG, RJ. Intelligence. Dialogues in Clinical Neuroscience, 2012, vol. 14, n. 1, p. 19-27. PMid:22577301.

STOODLEY, CJ. and SCHMAHMANN, JD. Evidence for topographic organization in the cerebellum of motor control versus cognitive and affective processing. Cortex, 2010, vol. 46, n. 7, p. 831-844. PMid:20152963. http://dx.doi.org/10.1016/j.cortex.2009.11.008.

VOOGD, J. The human cerebellum. Journal of Chemical Neuroanatomy, 2003, vol. 26, n. 4, p. 243-252. PMid:14729127. http://dx.doi. org/10.1016/j.jchemneu.2003.07.005.

YOUSEM, DM., YASSA, MA., CRISTINZIO, C., KUSEVIC, I., MOHAMED, M., CAFFO, BS. and BASSETT, SS. Intelligence and medial temporal lobe function in older adults: a functional MR imagingbased investigation. AJNR. American Journal of Neuroradiology, 2009, vol. 30, n. 8, p. 1477-1481. http://dx.doi.org/10.3174/ajnr.Al634.

YU, C., LI, J., LIU, Y., QIN, W., LI, Y., SHU, N., JIANG, T. and $\mathrm{LI}, \mathrm{K}$. White matter tract integrity and intelligence in patients with mental reterdation and healthy adults. NeuroImage, 2008, vol. 40, n. 4, p. 1533-1541. PMid:18353685. http://dx.doi.org/10.1016/j. neuroimage.2008.01.063. 